\title{
PENGARUH RETURN ON ASSETS, DEBT TO ASSETS RATIO, DAN OPINI AUDIT TERHADAP AUDIT DELAY
}

\author{
Abin Suarsa \\ STIE Muhammdiyah Bandung \\ abinsuarsa@stiemb.ac.id \\ Eki Muhamad Nawawi \\ STIE Muhammdiyah Bandung
}

\begin{abstract}
ABSTRAK
Penelitian ini bertujuan untuk menguji pengaruh variabel ROA, DAR dan Opini Audit terhadap Audit Delay pada Perusahaan Manufaktur Sektor Industri Dasar dan Kimia yang di BEI periode 2013-2014.

Teknik analisis yang digunakan adalah regresi berganda dan uji hipotesis menggunakan Uji t untuk menguji koefisien regresi parsial serta Uji f untuk menguji pengaruh secara parsial.

Hasil analisis menunjukkan bahwa ROA dan Opini Audit secara parsial berpengaruh berpengaruh terhadap Audit Delay. DAR berpengaruh namun tidak signifikan terdap Audit Delay. Hasil Uji Anova menunjukan secara simultan ROA, DAR, dan Opini Audit berpengaruh terhadap Audit Delay.
\end{abstract}

ABSTRACT

This research is performed in order to test the influence of the variable ROA, $D A R$ and audit opinion toward Audit Delay to the company of manufactur sector basic industrial and chemical in BEI for periode 2013-2014

Analysis technique used is multi regression and hypothesis test use t-statistic to test coefficient of regression partial.

The analyse result indicate that data ROA and Audit Opinion in partial significant toward Audit Delay. DAR in partial not significant toward Audit Delay. Anova test result show ROA, DAR and Audit Opinion in simultan significant toward AudIt delay.

Keyword: ROA, DAR, Audit Opinion and Audit Delay

\section{A. Pendahuluan}

Menerbitkan saham di bursa saham merupakan sumber pendanaan perusahaan dari masyarakat luas atau yang dikenal dengan go public. Perusahaan go public selalu diawasi kinerjanya oleh para stakeholder dalam aspek financial maupun non financial. Stakeholder memiliki kepentingan terhadap perkembangan suatu perusahaan, untuk mengetahui kondisi keuangan perusahaan dengan menganalisa laporan keuangan perusahaan (Munawir, 2014). Analisa laporan keuangan yang selalu digunakan oleh para investor yaitu Profitabiltas dan Solvabilitas.

Opini audit merupakan suatu pendapat yang diberikan oleh seorang auditor kepada klienkliennya atas laporan keuangan yang telah diaudit untuk menentukan apakah laporan keuangan tersebut wajar tanpa pengecualian atau tidak. Pendapat yang wajar tanpa pengecualian biasa disebut sebagai unqualified opinion yang artinya adalah pendapat auditor yang menyatakan bahwa laporan keuangan menyajikan secara wajar, dalam semua hal yang material, posisi keuangan, hasil 
usaha, perubahan ekuitas, dan arus kas suatu entitas sesuai dengan prinsip akuntansi yang berlaku umum di Indonesia.

Proses audit dilakukan sejak berakhirnya tahun buku perusahaan atau biasanya berakhir pada tanggal 31 Desember setiap tahunnya. Proses audit ini akan berlangsung sampai dengan tanggal ditandatanganinya laporan audit independent oleh akuntan publik, rentang waktu inilah yang dikenal dengan audit delay. Penelitian mengenai audit delay yang dilakukan oleh Dyer dan Mc.Hugh (1975) dalam Rahmawati (2008) menyatakan bahwa manajemen perusahaan besar memiliki dorongan untuk mengurangi Audit Delay dan penundaan laporan keuangan yang disebabkan oleh karena perusahaan besar senantiasa diawasi secara ketat oleh para stakeholder.

ROA, DAR dan opini audit merupakan hal yang menjadi perhatian stakeholder dalam menganalisa laporan keuangan dan merupakan bagian dari prosedur analisis yang dilakukan auditor selama proses audit. Apabila ROA perusahaan rendah, maka auditor akan melakukan tugas auditnya dengan lebih hati-hati karena adanya resiko bisnis yang lebih tinggi sehingga akan memperlambat proses audit dan menyebabkan penerbitan laporan auditan yang lebih panjang (Angruningrum dan Wirakusuma, 2013).

Berdasarkan uraian diatas, terjadi kesenjangan antara harapan publikasi laporan keuangan yang tepat waktu sesuai peraturan yang ditetapkan undang-undang dengan fakta yang keterlambatan publikasi laporan keuangan yang masih terjadi akibat audit delay serta hasil penelitian terdahulu yang masih terjadi research gap. Tujuan dari penelitian ini yaitu mengetahui seberapa besar pengaruh ROA, DAR dan opini audit secara simultan terhadap audit delay pada perusahaan manufaktur yang terdaftar di Bursa Efek Indonesia.

\section{B. KAJIAN TEORITIS}

Irham

Fahmi

(2013)

menyatakan bahwa Profitabilitas menunjukan keberhasilan perusahaan didalam menghasilkan keuntungan. Investor yang potensial akan menganalisa dengan cermat kelancaran sebuah perusahaan dan kemampuannya untuk mendapatkan keuntungan. Profitabilitas sering digunakan untuk mengukur kinerja perusahaan. Penelitian ini menggunakan Return On Asset (ROA) untuk menghitungan tingkat profitabilitas. Persamaan yang digunakan untuk menghitung Return On Asset Rasio (ROA) adalah sebagai berikut :

$$
\mathrm{ROA}=\frac{\text { EARNING AFTER TAX }}{\text { TOTAL ASSET }}
$$

Keterangan:

Return On Asset: Rasio Tingkat Profitabilitas

Earning After Tax: Jumlah laba bersih perusahaan

Total Asset: Jumlah asset yang dimiliki perusahaan

Menurut Munawir (2014) solvabilitas menunjukan kemampuan perusahaan dalam memenuhi kewajiban keuangan baik jangka panjang maupun jangka pendek.

Tingkat solvabilitas diukur dengan menggunakan Debt to Assets Ratio. Rasio ini melihat perbandingan utang perusahaan dengan membagi total utang perusahaan dengan total aset.

Persamaan yang digunakan untuk menghitung debt to asset ratio adalah sebagai berikut : 


$$
\mathrm{DAR}=\frac{\text { TOTAL LIABILITIES }}{\text { TOTALASSETS }}
$$

Keterangan:

$\begin{array}{ll}\text { DAR } & \text { : Debt to Asset } \\ \text { Ratio } & \\ \text { Total Liabilities } & \text { : Total Utang } \\ \text { Total Assets } & \text { : Total Aset }\end{array}$

Menurut Halim (2003), ada lima jenis opini yang dikeluarkan oleh auditor, yaitu:

1. Pendapat wajar tanpa
pengecualian opinion).

2. Pendapat wajar tanpa pengecualian dengan tambahan bahasa penjelasan (unqualified opinion with explanatory language).

3. Pendapat wajar dengan pengecualian (qualified opinion).

4. Pendapat tidak wajar (adverse opinion).

5. Pernyataan tidak memberikan pendapat (disclaimer of opinion).

Audit delay adalah jumlah hari kalender dari berakhirnya tahun fiscal sampai tanggal laporan auditor ( Ashton et.al, 1987). Audit delay diihat dengan mengukur selisih hari antara tanggal ditandatanganinya laporan auditor independent dengan tanggal tutup buku laporan keuangan tahunan.

Penelitian pengaruh profitabilitas terhadap audit delay sebelumnya dilakukan oleh Puspitasari dan Sari (2012), Petrolina (2007) dengan hasil penelitian profitabilitas berpengaruh terhadap audit delay, namun penelitian lain yang dilakukan oleh Margaretta dan Soepriyanto (2012), Kartika (2009), dan Ratnawaty dan Toto Sugiharto (2005) menghasilkan hasil yang sebaliknya.

Solvabilitas merupakan jumlah proporsi hutang yang dimiliki oleh perusahaan. Ketika perusahaan memiliki jumlah proporsi hutang yang lebih banyak daripada jumlah aset, maka auditor akan memerlukan waktu yang lebih banyak dalam mengaudit laporan keuangan perusahaan karena rumitnya prosedur audit akun utang serta penemuan bukti-bukti audit yang lebih kompleks dan konfirmasi terhadap pihak-pihak kreditur perusahaan.

Menurut Angruningrum dan Wirakusuma (2013), Puspitasari dan Sari (2012), dan Aryaningsih dan Budiartha (2014) melakukan penelitian pada tahun tersebut dengan hasil penelitian solvabilitas berpengaruh terhadap audit delay, sementara penelitian yang dilakukan oleh Ratnawaty dan Sugiharto (2005) menghasilkan kesimpulan sebaliknya.

Pengaruh opini audit terhadap audit delay dilakukan oleh Ratnawaty dan Sugiharto (2005), Aryaningsih dan Budiartha (2014), Kartika (2009), dan Petrolina (2007) dengan hasil opini audit berpengaruh terhadap audit delay, namun penelitian yang dilakukan Iskandar dan Trisnawati (2010) menghasilkan kesimpulan sebaliknya.

\section{METODE}

Penelitian ini berjenis kuantitatif deskriptif untuk mengetahui gambaran tentang variabel audit delay, profitabilias, DAR dan opini audit. Analisis ini hanya digunakan untuk menganalisis data disertai dengan perhitungan agar dapat memperjelas keadaan atau karakteristik data yang bersangkutan tanpa bermaksud menguji hipotesis.

Penelitian ini menggunakan audit delay sebagai variabel dependent dan ROA, DAR dan opini audit variabel independent.

\section{Populasi dan Sampel}

Populasi yang digunakan dalam penelitian ini adalah perusahaan-perusahaan 
manufaktur sektor industri dasar dan kimia yang terdaftar di Bursa Efek Indonesia yang menerbitkan laporan keuangan di tahun 2013 sampai dengan tahun 2014.

Pengambilan sampel menggunakan metode purposive sampling dengan kriteria yang diambil adalah:

1. Perusahaan manufaktur sektor industri dasar dan kimia yang terdaftar (listing) secara terusmenerus di BEI selama tahun 2013-2014, tidak melakukan IPO, Delisting, Maupun Relisting pada periode tersebut

2. Mengacu pada peraturan BAPEPAM X.K.2

3. Menampilkan data dan informasi yang digunakan untuk menganalisis faktorfaktor yang mempengaruhi audit delay untuk periode 2013-2014.

4. Menggunakan mata uang rupiah

\section{Metode Analisis Data}

Analisis regresi berganda digunakan apabila peneliti bermaksud meramalkan bagaimana keadaan naik turunnya variabel dependent bila dua atau tiga variable independent sebagai faktor prediktor dimanipulasi. (Sugiyono 2007).

Model regresi berganda dirumuskan dengan persamaan berikut:

AUDLY $=a_{0}+a_{1}($ ROA $)+$ $\mathbf{a}_{2}$ (DAR) $+\mathbf{a}_{3}$ (OPINI) $+\varepsilon$

Keterangan :

AUDLY: Audit Delay

$a_{0} \quad$ : Konstanta ( Harga $\mathrm{Y}$ bila $\mathrm{X}=$

0 )

$a_{1} \quad$ : Koefisien Regresi ROA

$\mathrm{a}_{2} \quad$ : Koefisien Regresi DAR

$a_{3} \quad$ : Koefisien Regresi Opini Audit

ROA :Tingkat Profitabilitas yang diproksikan dengan ROA

DAR : Tingkat Solvabilitas yang diproksikan dengan DAR

OPINI : Opini Audit $\varepsilon$

\section{: Error}

Koefisien determinasi $\left(\mathrm{R}^{2}\right)$ pada intinya mengukur seberapa jauh kemampuan model dalam menerangkan variasi variabel dependent dengan nilai di antara nol dan satu. Nilai $R^{2}$ yang kecil berarti kemampuan variabel-variabel independent dalam menjelaskan variasi variabel dependent amat terabatas. Menurut Ghozali (2013), nilai yang mendekati satu berarti variabel independent memberikan hampir semua informasi yang dibutuhkan untuk memprediksi variasi dependent .

Menurut Ghozali (2013) Uji statistik $\mathrm{F}$ menunjukan apakah semua variabel independent yang dimasukan dalam model mempunyai pengaruh secara bersama-sama mempunyai pengaruh terhadap variabel dependent.

Dalam uji F, kriteria pengambilan keputusan jika $\mathrm{F}$ lebih besar dari 4 maka $\mathrm{H}_{0}$ dapat ditolak pada derajat kepercayaan 5\%. Maka hipotesis alternatif diterima, yang menyatakan bahwa semua variabel independent secara serentak dan signifikan mempengaruhi variabel dependent.

Menurut Ghozali (2013) menyatakan bahwa uji $t$ pada dasarnya menunjukan seberapa jauh pengaruh satu variabel independent secara individual dalam menerangkan variabel dependent.

\section{HASIL DAN PEMBAHASAN}

Analisisa dengan menggunakan regresi berganda dapat dilihat pada tabel 1 berikut ini:

Tabel 1

Hasil Analisis Regresi Berganda 
Coefficients ${ }^{a}$

\begin{tabular}{llrrr}
\hline Model & \multicolumn{2}{c}{ Unstandardized Coefficients } & $\begin{array}{c}\text { Standardized } \\
\text { Coefficients }\end{array}$ \\
\cline { 3 - 5 } & & \multicolumn{1}{c}{ B } & Std. Error & Beta \\
\hline \multirow{3}{*}{1} & (Constant) & 68.780 & 3.420 & -.390 \\
& ROA & -62.105 & 18.764 & .172 \\
& DAR & 5.493 & 3.706 & .354 \\
\hline
\end{tabular}

a. Dependent Variable: AUDLY

Dari tabel 1 diatas dapat dibuat model regresi berganda dengan persamaan sebagai berikut :

AUDLY $=68,780-62,105($ ROA $)+5,493($ DAR $)+10,076($ OPINI $)+\varepsilon$

Keterangan :

AUDLY : : Audit Delay

ROA : Profitabilitas yang diproksikan dengan ROA

DAR : Solvabilitas yang diproksikan dengan DAR

OPINI : Opini yang dikeluarkan oleh auditor

$\varepsilon \quad:$ Error

Untuk hasil Uji Koefisien Determinasi dapat dilihat pada tabel 2 dibawah ini :

Tabel 2

Hasil Perhitungan Koefisien Determinasi Model Summaryb

\begin{tabular}{|c|c|c|c|c|c|}
\hline Model & $\mathrm{R}$ & R Square & $\begin{array}{l}\text { Adjusted R } \\
\text { Square }\end{array}$ & $\begin{array}{l}\text { Std. Error of } \\
\text { the Estimate }\end{array}$ & Durbin-Watson \\
\hline 1 & $.492^{a}$ & .242 & .213 & 12.244 & 2.009 \\
\hline
\end{tabular}

b. Dependent Variable: AUDLY

Adjusted $\mathrm{R}^{2}$ Dari tabel diatas menunjukan angka 0,213 yang berarti variabel ROA, DAR, Opini Audit mampu menjelaskan variabel Audit Delay sebanyak 21,3\% dan sisanya $78,7 \%$ dijelaskan oleh faktor lain yang tidak dijelaskan dalam penelitian ini.

Menurut Ghozali (2013) Uji statistik F menunjukan apakah semua variabel independent yang dimasukan dalam model mempunyai pengaruh secara bersama-sama mempunyai pengaruh terhadap variabel dependent.
Penelitian ini menggunakan ANOVA untuk menganalisis Uji F seperti yang ditampilkan pada tabel 3 dibawah ini : 
Tabel 3

Hasil Perhitungan Uji F

ANOVA

\begin{tabular}{|c|c|c|c|c|c|c|}
\hline \multicolumn{2}{|l|}{ Model } & $\begin{array}{l}\text { Sum of } \\
\text { Squares }\end{array}$ & $\mathrm{Df}$ & $\begin{array}{c}\text { Mean } \\
\text { Square }\end{array}$ & $\mathrm{F}$ & Sig. \\
\hline \multirow{3}{*}{1} & Regression & 3741.484 & 3 & 1247.161 & \multirow{3}{*}{8.319} & \multirow[t]{3}{*}{$.000^{b}$} \\
\hline & Residual & 11693.406 & 78 & 149.915 & & \\
\hline & Total & 15434.890 & 81 & & & \\
\hline
\end{tabular}

b. Predictors: (Constant), OPINI, DAR, ROA

Hasil Uji Anova menunjukan nilai $\mathrm{F}$ hitung 8,319 lebih besar dari $F$ tabel yaitu sebesar 2,72 dengan probalitas $0,000<0,05$ yang berarti secara simultan ROA, DAR dan Opini Audit berpengaruh terhadap Audit Delay.

Menurut Ghozali (2013) menyatakan bahwa uji $t$ pada dasarnya menunjukan seberapa jauh pengaruh satu variabel independent secara individual dalam menerangkan variabel dependent. Berikut hasil perhitungan uji t yang ditampilkan pada tabel 4

Tabel 4

Hasil Perhitungan Uji t Coefficients $^{a}$

\begin{tabular}{|c|c|c|c|c|c|c|}
\hline \multirow{2}{*}{\multicolumn{2}{|c|}{ Model }} & \multicolumn{2}{|c|}{$\begin{array}{c}\text { Unstanda } \\
\text { rdized } \\
\text { Coefficient } \\
\mathrm{s}\end{array}$} & $\begin{array}{l}\text { Stand } \\
\text { ardize } \\
\mathrm{d} \\
\text { Coeffi } \\
\text { cients }\end{array}$ & \multirow[t]{2}{*}{$\mathrm{t}$} & \multirow[t]{2}{*}{ Sig } \\
\hline & & B & $\begin{array}{c}\text { Std. } \\
\text { Erro } \\
r\end{array}$ & Beta & & \\
\hline & $\begin{array}{l}\text { (Co } \\
\text { nst } \\
\text { ant } \\
\text { ) }\end{array}$ & $\begin{array}{r}68.7 \\
80\end{array}$ & $\begin{array}{r}3.42 \\
0\end{array}$ & & $\begin{array}{r}20 \\
11 \\
1\end{array}$ & .00 \\
\hline 1 & $\begin{array}{l}\text { RO } \\
\mathrm{A}\end{array}$ & $\begin{array}{r}62 . \overline{1} \\
05\end{array}$ & $\begin{array}{r}18.7 \\
64\end{array}$ & -.390 & $\begin{array}{r}3.3 \\
10\end{array}$ & .00 \\
\hline & $\begin{array}{l}\mathrm{DA} \\
\mathrm{R}\end{array}$ & $\begin{array}{r}5.49 \\
3\end{array}$ & $\begin{array}{r}3.70 \\
6\end{array}$ & .172 & $\begin{array}{l}1.4 \\
82\end{array}$ & .14 \\
\hline & $\begin{array}{c}\text { OP } \\
\text { INI }\end{array}$ & $\begin{array}{r}10.0 \\
76\end{array}$ & $\begin{array}{r}3.03 \\
3\end{array}$ & .354 & $\begin{array}{r}3.3 \\
23\end{array}$ & .00 \\
\hline
\end{tabular}

a. Dependent Variable: AUDLY

Dari hasil analisis regresi diatas dapat dilihat bahwa variabel ROA dan Opini berpengaruh signifikan terhadap variabel Audit Delay, hal ini dapat dilihat dengan nilai signifikan dibawah 0,05. Namun variabel DAR memiliki nilai signifikan diatas 0,05 sehingga dapat dipastikan DAR tidak berpengaruh terhadap variabel dependent.

\section{Pengujian Hipotesis $1\left(\mathrm{H}_{1}\right)$ dan Pembahasan}

Dari tabel 3 dapat kita lihat bahwa nilai $t$ tabel sebesar 3,310 dengan arah pengaruh negatif, nilai ini lebih besar dari $t$ tabel yaitu sebesar 1,990. jadi, 3,310 > 1,990 dengan signifikan $0,001<0,05$ yang berarti $\mathrm{H}_{1}$ yang menyatakan ROA berpengaruh terhadap audit delay diterima.

Perhitungan diatas menjelaskan bahwa ROA berpengaruh negatif terhadap audit delay, ini berarti ketika perusahaan menderita kerugian atau tingkat ROA yang rendah, maka audit delay akan semakin panjang, ini terjadi karena ROA menjadi perhatian utama stakeholder dalam menilai kinerja perusahaan dan mengambil keputusan sehingga auditor akan lebih berhati-hati dalam melakukan audit terutama terhadap pos-pos yang menjadi faktor penyebab menurunnya tingkat ROA perusahaan.

\section{Pengujian Hipotesis $2\left(\mathrm{H}_{2}\right)$ dan Pembahasan}

Dari table 3 hasil statistik $\mathrm{t}$ untuk DAR yaitu sebesar 1,482 atau lebih kecil dari t tabel 1,990 dengan nilai signifikan $0,142>0,05$ yang berarti bahwa $\mathrm{H}_{2}$ yang menyatakan 
DAR berpengaruh terhadap audit delay ditolak.

Hasil ini berarti tingkat DAR yang ditentukan dengan proporsi utang terhadap total aset tidak berpengaruh terhadap audit delay, ini dikarenakan auditor dalam melakukan prosedur analisis lebih melihat pada ROA perusahaan yang menjadi sumber keuntungan bagi stakeholder, sehingga auditor dalam melaksanakan audit akan lebih fokus terhadap prosedur analisis yang melibatkan ROA walaupun mengaudit utang lebih rumit dan kompleks, namun hal itu tidak berpengaruh terhadap audit delay.

\section{Pengujian Hipotesis $3\left(\mathrm{H}_{3}\right)$ dan Pembahasan}

Hasil statistik t untuk opini audit pada tabel 3 menunjukan angka 3.323 dengan arah positif dengan nilai signifikan 0,01 , nilai statistik t 3,323 lebih besar dari nilai $\mathrm{t}$ tabel 1,990 dan nilai signifikan 0,001 berada dibawah 0,05 . yang berarti $\mathrm{H}_{3}$ yang menyatakan bahwa opini audit berpengaruh terhadap audit delay diterima.

Dari hasil penelitian diatas dapat disimpulkan bahwa opini audit yang diukur dengan variabel dummy menunjukan opini audit berpengaruh terhadap audit delay. Ini dikarenakan ketika pendapat wajar tanpa pengecualian dikeluarkan oleh auditor, pos-pos yang diaudit tersaji dengan wajar sesuai dengan standar yang ditetapkan oleh IAI sehingga audit delay akan lebih pendek atau cepat. Sebaliknya audit delay akan menjadi panjang ketika pendapat yang diterima adalah selain wajar tanpa pengecualian, hal tersebut mengindikasikan terdapat penyimpangan dalam laporan keuangan yang menyebabkan auditor harus lebih berhati-hati dan memeriksa serta mencari bahan bukti yang lebih kompeten untuk mendukung pendapat selain wajar tanpa pengecualian yang dikeluarkan.

Pendapat selain wajar tanpa pengecualian memiliki dampak negatif terhadap perusahaan terutama terhadap penilaian stakeholder terhadap perusahaan tersebut.

\section{E. SIMPULAN}

ROA berpengaruh negatif terhadap audit delay menjadi perhatian utama stakeholder sehingga auditor akan lebih berhatihati dalam melakukan audit terutama terhadap pos-pos yang menjadi faktor penyebab menurunnya tingkat profitabilitas perusahaan.

DAR tidak berpengaruh terhadap audit delay disebabkan auditor dalam melakukan prosedur analisis lebih melihat prosedur analisis pada tingkat ROA perusahaan yang menjadi sumber keuntungan bagi stakeholder, sehingga walaupun mengaudit utang lebih rumit dan kompleks, hal itu tidak berpengaruh terhadap audit delay.

Opini audit berpengaruh positif terhadap audit delay. Ketika pendapat wajar tanpa pengecualian dikeluarkan oleh auditor, pos-pos yang diaudit tersaji dengan wajar sesuai dengan standar yang ditetapkan oleh IAI sehingga audit delay akan lebih pendek atau cepat.

Saran peneliti adalah pihak auditor untuk dapat memperhatikan faktor ROA, DAR dan opini audit dalam semua tahapan audit baik perenanaan, pengujian maupun penyimpulan, sehingga dapat merencanakan waktu, tim dan hal lain sehingga tidak menjadi kendala dalam pelaksanaan prosedur audit yang berakibat pada panjangnya audit delay yang berakibat lain yaitu keterlambatan publikasi laporan keuangan.

Bagi penelitian selanjutnya, disarankan melakukan perluasan variabel yang mungkin menjadi 
faktor pengaruh audit delay dan menambah periode penelitian serta populasi penelitian.

\section{F. DAFTAR RUJUKAN}

Agoes Sukrisno. 2012. Auditing. Jakarta : Salemba Empat

Angruningrum Silvia dan Wirakusuma Made Gede. 2013. Pengaruh Profitabilitas, Leverage, Kompleksitas Operasi, Reputasi KAP dan Komite Audit Delay. E-Jurnal Akuntansi Universitas Udayana Vol 5 No. 2.

Arens and Loebbecke. 2003. Auditing. Jakarta : Salemba Empat

Aryaningsih Ni Nengah Devi dan Budiartha I Ketut. 2014). Pengaruh Total Aset, ingkat Solvabilitas dan Opini Audit Terhadap Audit Delay. EJurnal Akuntansi Universitas Udayana. Vol.7 No.3.

Ashton. et .al. 1987. 22An Empirical Analysis of Audit Delay. Journal of Accounting Research Vol. 25 No. 2 Autum. Printed in U.S.A.

Augustine, Osarumwense dan Ejiemen. 2012 Audit Delay and Audit Quality: The Nigerian experience. The International Journal Volume: 03, Number: 04. Research Journal of Social Science and Management.

Fahmi Irham. 2011. Analisis Laporan Keuangan. Bandung : Penerbit CV Alfabeta

Febrianty. 2011. Faktor yang Mempengaruhi Audit Delay Perusahaan. JURNAL EKONOMI DAN INFORMASI
AKUNTANSI (JENIUS) VOL.1 No.3.

Garrison and Norren. 2001. Akuntansi Manajerial. Jakarta : Salemba Empat

Ghozali Imam. 2013. Aplikasi Analisis Multivariate Dengan Aplikasi IBM SPSS 21. Semarang : Badan Penerbit Universitas Diponegoro

Halim Abdul. 2003. Auditing (Dasardasar Audit LAporan Keuangan). Yogyakarta : UPP AMP YPKN

Ismail Hashanah, Mustapha Mazlina dan Ming Oik Cho. 2012. Timeliness of Audited Financial Reports of Malaysian Listed Companies. International Journal of Business and Social Science Vol. 3 No. 22 [The Special Issue on Arts, Commerce and Social Science - Centre for Promoting Ideas, USA

Kartika Andi. 2009. Faktor yang Mempengaruhi Audit Delay Di Indonesia. Jurnal Bisnis dan Ekonomi (JBE), Maret 2009, Vol. 16, No.1

Kennedy, Emmanuel, dan Ikhatua Jude. (2012). Determinants of Audit Delay in Nigerian Companies: Empirical Evidence. Research Journal of Finance and Accounting 2222-1697 (Paper) ISSN 2222-2847 Vol 3, No 6.

Margaretta dan Gatot . 2009. Penerapan IFRS dan Pengaruhnya Terhadap Keterlambatan Penyampaian Laporan Keuangan. BINUS BUSSINES REVIEW Vol. 3 No. 2

Meylisa dan Trisnawati. 2010. Faktor yang Mempengaruhi Audit 
Report Lag Perusahaan. Jurnal Bsnis dan Akuntansi Vol 12 No. 3.

Munawir. 2014. Analisa Laporan Keuangan. Yogyakarta : Liberty Yogyakarta

Petrolina Anastasia Thio. 2007. Analisis Skala Perusahaan, Profitabilitas, Opini Audit, Pos Luar Biasa dan Umur Perusahaan Atas Audit Delay. Akuntabilitas Vol. 6

Puspitasari dan Anggraeni. 2012. Pengaruh Karakteristik Perusahaan Terhadap Lamanya Proses Penyelesaian Audit ( Audit Delay). Jurnal Akuntansi \& Auditing Volume 9. No.1.

Rachmawati Sistya. 2008. Pengaruh Faktor Internal dan Eksternal Perusahaan Terhadap Audit Delay dan Timeliness. JURNAL AKUNTANSI DAN KEUANGAN, VOL. 10, NO. 1.

Sugiyono. 2007. Statistik untuk Penelitian. Bandung : Penerbit CV Alfabeta

Vuko Tina and Cular Marko. 2014. Finding determinants of audit delay by pooled OLS regression analysis. Croatian Operational Research Review 81 CRORR 5(2014), 81-91 